\title{
Study on the Influence Mechanism of Asset Structure Adjustment on Earnings Quality
}

\author{
Liu Baifang ${ }^{1}$,Zhan Xuewei ${ }^{*}$ \\ ${ }^{1}$ Business School, Beijing Language and Culture University, \\ Beijing, 100083, China \\ liubaifang@blcu.edu.cn \\ ${ }^{2}$ Zhan Xuewei, Business School, Beijing Language and Culture University, \\ Beijing, 100083, China, $1779158111 @ q q . c o m$
}

\begin{abstract}
This paper studied the impact of asset structure adjustment on the earnings quality by mathematical analysis methods. The adjustment of enterprise asset structure affects the quality of surplus production and the quality of earnings confirmation. Due to the asymmetry of information and the defects of accounting theory, the accounting confirmation of manipulative accrual earnings has become an important part of the evaluation of the earnings quality. While the constraints of information environment and the limitations of confirmation means make it likely reasonable to exist for a long time for earnings management behavior.
\end{abstract}

Keywords-Earnings quality; Asset structure; Adjustment; Mechanism

\section{INTRODUCTION}

Earning quality has been closely concerned by academics. Earnings management is an important factor affecting the earnings quality. Many scholars have studied the earnings quality of enterprises from the perspective of earnings management. Gao Lei and Zhang Jie (2009) 1 thought that there are defects in corporate governance structure, which makes the earnings management of listed companies in China more common, thus affecting the quality of enterprise earnings. Sun Liang, Liu Chun (2008) 2 suggested that the incentive effect of operating performance determines the degree of earnings management, rather than the restriction role of corporate governance, especially the main operating rate of return has an important influence on earnings management. Mao Xinshu, Dai Deming (2009) 3 researched the enterprise's earnings management behaviors from the perspective of accounting system reform, they thought after deducting the handling accrued profits, prudence principle in accounting system still reflected in the surplus robustness of listed companies; Wang Yutao, Xue Jian, Chen Xiao(2009)4studied the impact of accounting standards change on corporate earnings management behavior, the research results indicate that managers are using the differences between old and new accounting standards for enterprises to adjust the motive of the accrued surplus; Luo Jinhui, Wan Difang, Li Chao (2010) argued that the listed companies have a clear preferences for providing a "compliance" adjustment of asset impairment preparation structure to achieve the purpose of earnings management under the motivation of the escape and cater to the new enterprise accounting standards system; Zhang

This Research findings is supported by the special fund of the basic research of the Central University, project number: 16ZDD01. weidong (2010) 5believed that Chinese listed companies have the opportunity to use directional placement to deliver benefits to the controlling shareholders.

Although these studies are variable, they lack relevant works on corporate surplus from the perspective of enterprise asset structure change. The realization of cash flow and surplus finally depends on the manager's production and management activities. Production and operation activities are closely related to earnings management. Research on earnings management is essentially a study of two problems, one is the production of surplus and the other is the confirmation of surplus. In the final analysis, there is only one source of corporate surplus, namely, the production and operation of enterprises. The production and operation activities of enterprises produce surplus, but information asymmetry is ubiquitous, how to confirm the surplus becomes another important issue. With the deepening of enterprise production and operation activities, the form of the enterprise assets changed: long-term assets in different forms of conversion into enterprise's production costs, other assets in the form of different flow throughout the whole process of enterprise production and management. Corresponding to the change of different assets of the enterprise, the enterprise cash flow or surplus will flow into the enterprise in different distribution form. The diversification of the distribution of earnings into the enterprise provides many perspectives on how to identify the surplus. Make sure that the view of the surplus is different and the understanding of corporate profits is different. For example, corporate profits have economic profit and accounting profit, as well as taxable profit and accounting profit classification. Even in the same perspective, there are many ways to identify a surplus. Different approaches lead to a difference in the earnings that the company eventually confirms.

Business managers often choose appropriate validation methods to meet different goals. According to the actual needs, the manager may choose to smooth the income, or choose the large write-off, or choose the inflated surplus. At present, most of the literature research the up or down earnings management behaviors. These studies essentially research on how to confirm the surplus, but ignore the research on the origin of the surplus. This study is one-sided if it is limited to the study of earnings management behavior using accounting methods 
rather than the generation mechanism of enterprise surplus. Comprehensive research must be traced back to how the surplus is produced and how the surplus is identified. These two aspects must be effectively combined. If the research on these two aspects cannot be effectively coordinated and integrated, then the conclusions obtained are inevitably biased. We need to find a perspective: we can study the surplus production and the convergence of earnings confirmation.

The economic essence of enterprise growth is that labor causes the value transfer and appreciation of enterprise assets. Different disciplines are different to the definition and classification of enterprise assets, such as the understanding of industry economics and accounting for assets has the difference, however, the changes in the enterprise capital structure adjustment dynamically reflect the production and business operation activities of enterprise is the consensus. The continuous adjustment of enterprise asset structure in the accounting period reflected the mechanism of the generation of surplus and confirmation: in the accounting period, the enterprise asset structure adjustment can reveal the process of enterprise surplus produce; At the end of the accounting period, After confirming that the enterprise surplus, the final enterprise asset 1 structure will be formed. The production and operation of the enterprise is continuous, and this continuous process is displayed through the continuous dynamic adjustment of the enterprise's asset structure; the generation and recognition of enterprise surplus continue with the dynamic adjustment of enterprise asset structure. Thus researching on the enterprise asset structure changes continuously can understand the enterprise surplus and confirmed that the mechanism of formation, thus for comprehensive study of earnings management behavior of enterprise to provide a wider perspective.

The remainder of this paper is arranged as follows: the second part analyzes the influence mechanism of asset changes on the surplus, and tries to analyze the mechanism of the effect of asset changes and asset correlation on the surplus. The third part based on the second part explicitly analyses the influence mechanism of asset structure optimization adjustment on earnings quality, the fourth part summarizes the full text and analyses the deficiency of research.

\section{THE IMPACT OF ASSET ALTERATION ON EARNINGS}

\section{A. Assets Alteration}

The enterprise surplus comes from two aspects: the enterprise assets and the labor of the employees, namely $\mathrm{K}$ and L. From the perspective of enterprise management, enterprise profit depends on the management behavior of regulators. The management strategy of regulators is realized through the adjustment of assets. The adjustment of enterprise assets mainly refers to the growth of asset size and the change of proportion of different asset items. The adjustment of the scale of enterprise assets or the change of the capital structure results in the fluctuation of the profitability of the enterprise and the change of the risk level. Whether the fluctuation of enterprise income ability or risk level can cause the fluctuation of the enterprise's earnings, which may bring a lot of problems about how to confirm the earnings.
Classical theory that confirmed that the surplus of the enterprise from the angle of capital preservation considered that enterprise surplus is a part of an enterprise owner or a shareholder that can be allocated in the case of the equivalent value of the final assets and the initial assets of the period. The perspective of capital preservation can be divided into two schools: physical preservation and monetary preservation, in which physical preservation is the most basic theory. For the sake of simple analysis, this article does not distinguish between the two points of view, just using the perspective of capital preservation, studies the impact of the adjustment of asset structure on the production and recognition of enterprise income, and reveals the endogenous mechanism of earnings management.

According to capital preservation hypothesis, the production and operation process of an enterprise can be interpreted as:

Initial assets + current income - current expenses $=$ final assets, the left can be adjusted to the end assets - the initial assets = current income - current expenditures. Let's assume that Ait is a specific asset for an enterprise, where i can be a liquid asset project or a non-current assets project. Eit is the specific surplus project of the enterprise, where $\mathrm{i}$ can be an operating surplus project or a non-operating surplus project; $\mathrm{i}=$ $1,2,3 \ldots$, to distinguish different asset items or surplus projects, $t$ represents different time points, and the enterprise's surplus is based on the assumption of capital preservation:

$$
\mathrm{E}_{\mathrm{t}}=\Delta \mathrm{A}_{\mathrm{t}}=\mathrm{A}_{\mathrm{t}+1}-\mathrm{A}_{\mathrm{t}}
$$

The upper class is divided by the initial assets At, then

$$
\frac{E_{t}}{A_{t}}=\frac{\Delta A_{t}}{A_{t}}=\frac{A_{t+1}-A_{t}}{A_{t}}
$$

Then, $E_{t}=\frac{A_{t+1}-A_{t}}{A_{t}} * A_{t}=\frac{\sum\left(A_{i t+1}-A_{i t}\right)}{A_{t}} * A_{t}=\sum\left(\Delta \frac{A_{i t}}{A_{t}}\right) * A_{t}(1)$

The surplus expression 1 shows that the earnings of enterprises depend on two aspects: the efficiency of enterprise asset adjustment and the scale of enterprise assets. $\sum\left(\Delta \frac{A_{i t}}{A_{t}}\right)$ represents the efficiency of enterprise asset adjustment. Or it can be said that the enterprise asset structure optimization adjustment efficiency; $A_{t}$ represents the scale of the enterprise assets. The surplus expression 1 shows that when the enterprise asset size stability, the efficiency of enterprise asset structure optimization determines the enterprise surplus, with the improvement of management of production and business operation ability, enterprise asset structure adjustment efficiency improves, enterprise surplus grows; On the contrary, if the enterprise asset structure adjusts with a low efficiency, the enterprise surplus may grow slowly, even negative growth.

The efficiency of adjustment and optimization of enterprise asset structure depends on two aspects: first, the direction of the change of asset structure; second, the magnitude of changes in the asset structure. Depending on liquidity and profitability, enterprise assets can be divided into current assets and non-current assets. Accordingly, the asset structure of enterprises can be different combinations of liquidity and profitability. The direction of the change of corporate asset structure adjustment is a combination of liquidity and 
profitability after the manager measures the liquidity and profitability of the assets. When the currency is stable, the magnitude of the enterprise's asset structure adjustment is relatively easy to be determined. However, when inflation occurs, the adjustment range of the enterprise's asset structure may be rectified.

Assuming that the liquidity of the asset is $L \in[0,1]$, the asset profitability is $E \in[0,1]$, and the relationship between enterprise asset structure adjustment and enterprise surplus can be expressed as:

$$
\mathrm{E}_{\mathrm{t}}=\sum\left(\Delta \frac{\mathrm{A}_{\mathrm{it}}}{\mathrm{A}_{\mathrm{t}}}\right) * \mathrm{~A}_{\mathrm{t}}=\sum \mathrm{F}(\mathrm{L}, \mathrm{E}) * \mathrm{~A}_{\mathrm{t}} \text {, the definition of }
$$
function $F$ is the capital structure adjustment efficiency function.

The asset structure adjustment efficiency function is not a realition of monotonous increment or decreasing, it can be decreasing function, also can be increasing function. The non-monotonicity of the asset structure adjustment efficiency function is rooted in the uncertainty of enterprise production and operation. The accounting theory is divided on how to confirm and measure assets, which deepens the non-monotonicity of the asset structure adjustment efficiency function.

$E_{t}=\sum F(L, E) * A_{t}$ shows that the enterprise surplus is affected by the efficiency function of asset structure adjustment, and the surplus depends on the efficiency of the adjustment of enterprise asset structure. The relationship between surplus and asset structure adjustment needs to be discussed deeply. In general, the adjustment of corporate asset structure is efficient, and the corporate surplus may be higher, but it is also possible that the asset structure adjustment is efficient, while the surplus may be lower. The surplus and the efficiency of the adjustment of enterprise asset structure are not a linear correspondence, which due to the complexity of asset structure adjustment.

\section{B. Asset Correlation}

The diversity of enterprise assets determines the complexity of asset structure adjustment. As above analysis, according to the classification of liquidity and profitability, enterprise assets can be divided into assets with high liquidity and low profitability (such as cash, bank deposits, etc.), or assets with high profitability and low liquidity (such as long-term equity investment, investment in fixed assets, etc.). The adjustment of enterprise asset structure may involve the adjustment of a combination of different liquidity and profitability. These different portfolio adjustment changes will lead to the corresponding changes in the liquidity and profitability of all assets of the enterprise. The changes in the overall liquidity and profitability of enterprise assets are closely related to the adjustment of different asset portfolios, but this correlation is not a simple linear relationship. This correlation is mainly dependent on the direction and magnitude of the adjustment of the asset structure discussed in the previous article, and is also affected by the correlation between the asset items that have been adjusted and changed.

Assuming that there are two assets $m$ and $n$, the total assets are $m+n$, which is analyzed by the previous text.

$$
\begin{array}{r}
\mathrm{E}_{\mathrm{t}}=\sum \mathrm{F}(\mathrm{L}, \mathrm{E}) * \mathrm{~A}_{\mathrm{t}}=\left[\delta \mathrm{F}_{\mathrm{mn}}(\mathrm{L}, \mathrm{E})+\mathrm{F}_{\mathrm{m}}(\mathrm{L}, \mathrm{E})+\mathrm{F}_{\mathrm{n}}(\mathrm{L}, \mathrm{E})\right] * \\
\mathrm{~A}_{\mathrm{m}+\mathrm{n}}(2)
\end{array}
$$

In which, $\delta \in[-1,1]$ is the correlation coefficient of the change of capital $\mathrm{m}$ and $\mathrm{n}$. The earnings expression 2 shows that the corporate earnings is affected by the direction and amplitude of the asset structure adjustment, and is also restricted by the correlation between different asset items. If $\delta_{\mathrm{mn}}=1$, the capital $\mathrm{m}$ and $\mathrm{n}$ also adjust the change of enterprise earnings with superposition effect .Or if $\delta_{\mathrm{mn}}=-1$, $\mathrm{m}$ and $\mathrm{n}$ are adjusted to offset the changes in corporate earnings. Of course, this is only the extreme case of the correlation between different assets. In the real process of production and operation, the range of correlation coefficient between enterprise assets tends to be between -1 and 1 . In general, enterprises have many types of capital, the correlation coefficient between different assets have positive and negative. Expression by formula 2, when managers adjust and optimize the enterprise asset structure, superimposed effect and offset effect are intertwined. The intertwining effect and countervailing effect complicate the relationship of enterprise asset structure adjustment and earnings.

Simple examples can be used to determine the impact of the correlation between different assets on corporate earnings. The company has two kinds of products, including the profit of product $\mathrm{A}$ and the loss of product $\mathrm{B}$, among which the correlation coefficient of the two products is: $\delta_{\mathrm{ab}}$. The fixed production cost of the company that is shared by product $\mathrm{B}$ is $\mathrm{f}$. The manager's adjustment of the asset allocation or asset structure of the enterprise depends on $\delta_{\mathrm{ab}}$ and $\mathrm{f}$.

(1) If $\delta_{\mathrm{ab}} \geq 0, \mathrm{~B}$ products have a positive correlation with A, B products not only have a positive role in promoting A products (the role might be performed to share the production cost of A product and improve the profitability of A product, etc), and to be able to share part of the fixed cost of production, $\mathrm{B}$ products have a positive effect on corporate surplus. In this case, the manager will continue to produce $\mathrm{B}$ products or optimize the strategy of B products to ensure the profitability of the enterprise.

(2) Or if $-1 \leq \delta_{\mathrm{ab}} \leq 0$, B product is negatively related to product A, B products can share the fixed cost of the enterprise, but the product has a negative effect on the product. In this case, the management optimization of the enterprise assets strategy is more complex. Suppose that the inhibitory function of $\mathrm{b}$ product to A product is $\mathrm{F}\left(\delta_{\mathrm{ab}}\right)$, if $\mathrm{F}\left(\delta_{\mathrm{ab}}\right)<f$, although $\mathrm{B}$ products have inhibitory effect on A product, but it has positive effect to the enterprise overall cost reduction, and share the fixed cost is greater than its inhibitory effect on A product, the product $\mathrm{B}$ has positive role to the enterprise surplus, therefore, the managers can consider to continue to produce ethyl products, and the asset structure optimization measures, make B product minimal inhibitory effect on A product, and share the enterprise fixed costs the most. If $\mathrm{F}\left(\delta_{\mathrm{ab}}\right)>f$, B product inhibition of A product is greater than its share of enterprise fixed cost of production, at this point, $B$ products only negative effect to the enterprise surplus, so the managers can choose to stop producing B products, at the same time to optimize A product of the production process, improve the profitability of A product. 
Inductive analysis of the above, we know the generation mechanism of enterprise earnings is affected by the phase relationship between different assets, are also affected by the efficiency of the enterprise asset structure adjustment, the adjustment efficiency is embodied in the direction and amplitude. When the managers adjust the direction and amplitude of the asset structure chooses different profitability and liquidity combination, the profitability of the enterprise changes accordingly. Correlation between different assets makes the relationship of managers' asset structure adjustment becomes complicated. Managers need to weigh the correlation of different assets and the profitability of specific assets so as to determine the asset structure adjustment strategy for guaranteeing the stability and growth of enterprise earnings.

\section{THE INFLUENCE OF THE ADJUSTMENT OF ASSET STRUCTURE ON EARNINGS QUALITY}

\section{A. Earnings Quality}

It is not an easy proposition to define the connotation of earnings quality. To this day, scholars still have opinions on it and there is no unified conclusion. Some scholars start from the perspective of quality attribute and think when the enterprise earnings meet the quality requirements of reliability, relevance and timeliness, it is high quality. This view is based on qualitative analysis, although it can guide the actual work, it has little effect. Some scholars, from the point of view of earnings confirmation, believe manipulative accrual earnings makes up relatively small in earnings quality is high quality. This view is based on accounting confirmation, and it is a mainstream view to study the earnings quality from the constitution of the earnings information, and it has strong practicability and operability. There are also scholars from the perspective of earnings disclosure to study, their think when earnings quality is reflected in the disclosure of earnings information will cause a significant response and when the enterprise earnings quality is lower the investors is not take reaction. This view based on the market effective theory, from the consequences of earnings information disclosure to infer the high or low of the earnings quality. Although the view is biased, in practice, this view is more popular.

There are several points of view to define the earnings quality. Although each has its own expertise, all theories have obvious shortcomings. In fact, for understanding the earnings quality, we should contact the process of the earnings quality of producing, confirming and disclosing earnings and can't study from a certain node. The earnings quality is an organic whole, and it is necessary for the system to consider the production link of the surplus, the confirmation link of the surplus and the disclosure of the surplus, so as to comprehensively and accurately understand the connotation of earnings quality. The ideal model of earnings quality assessment is to evaluate the enterprise's profitability of production capacity, also want confirmed quality of appraisal enterprise surplus, but pay close attention to the enterprise surplus disclosed after the reaction of the market. With the rise of the decision-making serviceability, the paper that studies earnings quality from the consequence of earnings disclosure is springing up like mushrooms. However, the most important point to consider in evaluating the earnings quality is the controllability of earnings quality. It is different for the managers to say the generation of surplus, the confirmation of surplus and earnings disclosure, etc. Especially to establish a point of the quality of earnings disclosure on the efficient market hypothesis, this point regard market valuation as a standard to study earnings quality, this makes managers preference for earnings management to cater to the market, even selected disclosure of earnings information, so as to improve the quality of "earnings". Market effectiveness is not a defined concept, and it is difficult to sustain the earnings quality to cater the investors' preferences. So, considering the earnings quality controllability, this paper mainly studies the asset adjustment produce the quality of earning production and confirmation (the research to study optimize asset structure adjustment mechanism effect on the earnings quality of production and confirmation).

\section{B. Impact Mechanism}

In the second part of this paper, we analyze the impact mechanism of the adjustment of asset structure to the surplus production and confirmation. In short, the asset structure adjustment efficiency and the asset correlation influence the enterprise earnings. This part will deeply analyze the influence mechanism of enterprise asset structure adjustment on earnings quality. The asset operation of the enterprise generates a surplus. With the value migration of enterprise assets, practicality consumption and capital supplement, the enterprise assets are adjusted dynamically. Accounting theory to make the enterprise assets to different subdivision, proportion of assets in different subdivision called asset structure, then accounting theory for the adjustment of asset structure changes to bridge to the production and operation activities of the enterprise with the confirmation of the earnings. The dynamic optimization process of asset structure runs through the whole process of surplus production and accounting confirmation.

How to evaluate the quality of surplus production? The stable and sustainable profitability of the enterprise is the performance of the high quality of the surplus. Stable and sustainable profitability can be evaluated in two ways. One is stable cash flow. Cash flow is an important factor to evaluate the enterprise value. As the cash flow continues to grow steadily, the corporate earnings increases and the enterprise value increases. Another is the sustainability of profitability. Enterprise assets have stable and sustainable profitability, so as to guarantee the survival and development of enterprises. Stable cash flow is the first condition for the survival of the enterprise, otherwise, the enterprise will be in financial distress or even bankruptcy liquidation; Sustainable profitability is a necessary condition for the development and expansion of the enterprise. Without sustained and stable profitability, the enterprise will be a castle in the air, which will eventually collapse.

How to evaluate the quality of accounting confirmation of earnings? Enterprises have a clear cut of the non-manipulative accrual earnings and manipulative accrual earnings are the performance of the earnings confirmation of higher quality. In cash basis, there is no accrued and receivable theory and the confirmation problem of enterprise surplus also does not exist; Under the accrual basis of accounting, how to 
better confirm and match accrued profit become the key problem of accounting theory and accounting practice, hence we produce the quality of earnings confirmation for solving the problem, and ultimately affect the enterprise earnings quality. As described in the introduction, many scholars have studied the earnings quality and achieved fruitful achievements from the analysis of manipulative and non-manipulative accrual earnings. The early jones model, the modified Jones model and the nonlinear Jones model and Healy model, DeAngelo model and KS model, etc., the basic thoughts of these models are derived from analysis of manipulative accrual earnings, and this paper also analyses the earnings quality. Although these models have different emphasis, their basic research conclusions are unified: the manipulative accrual earnings are an important means for managers to carry out earnings management, thus affecting the earnings quality. From the influence of the adjustment of asset structure on the quality of earnings confirmation, managers choose manipulative accrual earnings to manage the earnings is not necessarily intentional, but often limited by the objective environment and the limitations of accounting theory, managers not clearly and accurately analyze the accrual earnings, leading to the earnings management behavior. The following parts will analyze the influence mechanism of asset structure adjustment on earnings quality from three links, such as production quality, quality confirmation quality and the quality of earnings disclosure.

The earnings quality function is $Q_{E}, F$ is the efficiency function of the asset structure adjustment, the earnings production quality function is $\mathrm{P}_{\mathrm{E}}$, the earnings recognition quality function is $\mathrm{C}_{\mathrm{E}}$, and the earnings disclosure quality function is $\mathrm{D}_{\mathrm{E}}$, then the influence mechanism of asset structure adjustment and optimization on earnings quality can be expressed as:

$$
\mathrm{F} \rightarrow \mathrm{Q}_{\mathrm{E}}=\mathrm{P}_{\mathrm{E}} * \mathrm{C}_{\mathrm{E}} * \mathrm{D}_{\mathrm{E}}
$$

Because the disclosure quality is not controlled by the management of the adjustment and optimization of the asset structure, it is more dependent on the market efficiency and the rationality of the investor. This paper is devoted to the analysis of earnings quality from the perspective of optimizing the asset structure. Therefore we assumed that the enterprise earnings disclosure quality is $\alpha_{t}$, the meaning of $\alpha_{t}$ is in period of the earnings disclosure quality, the $\alpha_{t} \in(0,1]$, alpha when $\alpha_{t}=1$ 时, the corporate earnings disclosure quality is 1 , said the manager truthfully disclosure of corporate earnings.

In the second part, it is shown that the process of fitting the production and confirmation of the enterprise earnings can be fitted by the adjustment and optimization of the asset structure. Combined with the influence mechanism expression 3, the overall the enterprise earnings quality can be expressed as

$$
\int_{t-1}^{t} F(s) d s \rightarrow \alpha_{t} P_{E} * C_{E}
$$

The enterprise asset structure adjustment vector, capital liquidity, profitability and sustainability is one of the asset structure adjustment according to the above vector, sets $\in$ $(\overrightarrow{\mathrm{L}}, \overrightarrow{\mathrm{E}} \ldots \ldots)$. In this paper, the liquidity and profitability of asset are the focus of this paper.
Earnings can be divided into two parts: cash flow (Cash) and accruals (Accrued profit, referred to as Apro), both in the implementation of recovery system or accrual basis, cash flows are not accrued to and accrual requires careful treatment, the earnings quality analysis of 4 type decomposition cash flow and accruals have two parts:

$$
\begin{aligned}
& \int_{\mathrm{t}-1}^{\mathrm{t}} \mathrm{F}(\mathrm{s}) \mathrm{ds} \rightarrow \alpha_{\mathrm{t}} \mathrm{P}_{\mathrm{E}} * \mathrm{C}_{\mathrm{E}}=\alpha_{\mathrm{t}}\left(\mathrm{P}_{\mathrm{E}} \text { Cash } * \mathrm{P}_{\mathrm{E}} \text { Apro }\right) \mathrm{C}_{\mathrm{E}}= \\
& \alpha_{\mathrm{t}}\left(\text { Cash } * \mathrm{P}_{\mathrm{E}} \text { Apro }\right) \mathrm{C}_{\mathrm{E}}
\end{aligned}
$$

Because the cash flow is not accrued, the non-manipulative accrual earnings is Ndisa, and the manipulative accrual earnings is Disa.

$$
\begin{aligned}
\int_{\mathrm{t}-1}^{\mathrm{t}} \mathrm{F}(\mathrm{s}) \mathrm{ds} \rightarrow \alpha_{\mathrm{t}} \text { Cash } * \text { Ndisa } * \mathrm{C}_{\mathrm{E}}\left(\mathrm{P}_{\mathrm{E}} \text { Disa }\right) \\
=\alpha_{\mathrm{t}}\left[\text { Cash } * \text { Ndisa } * \mathrm{C}_{\mathrm{E}}\left(\mathrm{P}_{\mathrm{E}} \text { Disa }\right)\right]
\end{aligned}
$$

Simplify the upper form to:

$$
\int_{\mathrm{t}-1}^{\mathrm{t}} \mathrm{F}(\mathrm{s}) \mathrm{ds} \rightarrow \alpha_{\mathrm{t}}\left[\text { Cash } * \text { Ndisa } * \mathrm{C}_{\mathrm{E}}\left(\mathrm{P}_{\mathrm{E}} \text { Disa }\right)\right]
$$

Expression 6 clearly expresses the influence mechanism of asset structure adjustment on enterprise earnings quality: the optimization and adjustment of asset structure affects the quality of surplus production and the quality of earnings confirmation; Optimizing adjustment of asset structure directly affects the cash flow of surplus, because the accounting confirmation problem of cash flow is nothingness, managers of enterprises difficult to through the accounting method to smooth or hidden the problem of cash flow; earnings confirm quality mainly displays in the accounting confirmation of the manipulative accrual earnings, due to information asymmetry is an universal phenomenon, restrictedly, thus the accounting theory about how to make sure there's no perfect way, the information asymmetry and defective confirmation method makes the behavior of earnings management must exist. In study of earnings management's influence on the earnings quality, we must consider the biased error of accounting method for manipulative accrual earning, to comprehensive weight the economic consequences of managers' earnings management behavior. Of course, the non-manipulative accrual earnings also have these problems, but it is not as important as manipulative accrual earnings for the impact of earnings quality.

\section{CONCLUSION}

The paper takes advantage of detailed analysis of the impact mechanism on earnings quality and the enterprise asset structure's impact mechanism on earnings quality, considers that managers' capital structure adjustment strategy has important effect on earnings quality. This effect is mainly reflected in the influence of the management's asset structure adjustment strategy on the quality of surplus production and the quality of earnings confirmation. In the case of the information asymmetry and the defects of accounting theory, the accounting confirmation of the manipulative accrual earnings has become an important content of the evaluation of the earnings management and also affects the earnings quality. The objective and constraint conditions makes managers' earnings management behavior can reasonably exist for a long time, so we study the earnings quality and earnings 
management must be noted the constraint environment of managers and objectively evaluate the earnings management behavior, and not all of the earnings management behavior are considered to be can eliminate or needed to contain. Under the constraints of information asymmetry and the defects of accounting theory, earnings management is not only inevitable, but may even be necessary.

\section{REFERENCE}

[1] Gao Lei, Zhang Jie. Corporate governance, earnings management and enterprise growth. Economic Theory and Business Management [J], 2009(12):53-59.

[2] Sun Liang, Liu Chun. What determines the difference of earnings management degree: corporate governance or performance? China Accounting Review [J], 2008(3):79-92.

[3] Mao Xinshu, Dai Deming. Accounting institution reform, earnings conservatism and earnings management. Accounting Research [J], 2009(12):38-46.

[4] Wang Yutao, Xue Jian, Chen Xiao. Enterprise accounting choice and earnings management. China Accounting Review [J], 2009(9):255-268.

[5] Zhang Weidong. Directional secondary issue of new shares and earnings management. Management World [J], 2010(1):54-73. 